\title{
A THEOLOGICAL PERSPECTIVE ON THE PHENOMENON OF LIFE: INTRODUCTION INTO THE BIOS, PSYCHE, AND ZOE
}

\begin{abstract}
A b s t r a c t. Life is such a beautiful and unique phenomenon. It cannot be described by a single definition, as it manifests itself in many different ways. Therefore, the phenomenon of life must be captured as a whole and by including its essential planes. The authors of the paper did interdisciplinary research. Their task was an exploration of the issue of life on three planes: bios (life in its core manifestations), psyche (intelligent and conscious life), and zoe (life that transcends itself). The collected data gives an appropriate perspective for theological insight. This approach determines a methodology that is interdisciplinary and very theological in character. This in-depth perspective enables the whole phenomenon to be understood in its transcendental function. Life from its very inception emerges toward "something more." The final goal of this transcendental dynamism is ever-living God.
\end{abstract}

Key words: bios; psyche; zoe; religion and science; transcendentality; contemporary theology.

\section{INTRODUCTION}

Is it possible to capture the essence of life? At present, many different branches of science dealing with the issue of life provide very interesting data. However, each of them captures this phenomenon in a narrow and precise field, so although their conclusions are pertinent, they are also limited. Despite the tremendous intel-

AnNa PęDrak, MA (can. licentiate) - doctoral student of dogmatic theology at the Faculty of Theology of the John Paul II Catholic University of Lublin; e-mail: annapedrak.sl@gmail.com; ORCID: http://orcid.org/0000-0001-9813-5277.

Rev. Dr. Kamil E. Duszer, priest of the Siedlce diocese, teacher of dogmatic theology at the Higher Theological Seminary of the Siedlce diocese; e-mail: kamilduszek@yahoo.com; ORCID: http://orcid.org/0000-0002-4176-5945. 
lectual effort put in by scientists, life seems to elude all attempts at encapsulation in words, terms, or systems. The voice of theology can be helpful in this situation. Jesus Christ said of Himself, "I am life." This light of Christian belief could provide useful insight into the results of scientific research.

This article attempts to capture the phenomenon of life theologically. After all, a holistic outlook on life requires the inclusion of the research findings of other disciplines. This approach determines both the method and the structure of the work. Here, the phenomenon of life will be addressed on its three essential planes: bios - life in its core manifestations; psyche - intelligent and conscious life; zoe life that transcends itself. Analysis of these three layers purposes to emphasize the transcendentality aspect of the whole phenomenon.

The paper is by nature introductory. It does not attempt the construction of a systematic model of life. The task is not a model of life, but rather a preliminary insight into the phenomenon. In some cases, initiated concepts will not be fully accomplished due to the limited parameters of the article. The authors recognized this in advance because of a broader vision for further publications. Moreover, some issues have already been presented in other recent works, especially a theological interpretation of the bios as a vestigium Dei, and the psyche as an umbra Dei.

\section{THE PHENOMENON OF LIFE: THE BIOS}

The Greek term Bios is probably understandable to everyone and could hardly be translated any other way than simply life. Since the 19th century, bios has universally been associated with life in the context of its evident and basic signs. Thanks to the paradigms of modern life science, one can now describe biological life in a far more precise way than was possible in the past. It can be said the bios is composed of five main aspects: separation and unity (e.g. thanks to cell membrane), metabolism and growth, reproduction, struggle (e.g. against entropy), evolution.

This understanding of biological life is the object of study of many fields of science. It is not possible to analyze all of their achievements in detail. Further theological analysis will be limited to three planes selected to show the complexity of the problem in a cross-sectional way.

\section{Life and entropy}

In accordance with the second law of thermodynamics, every closed-loop system has a state function known as entropy. In brief, entropy can be described 
as a measure of energy dissipation. When a cup of hot tea cools down, its energy dissipates, which means the entropy of the system is positive. A similar example is the cosmos - it too is subject to a process of entropy. The energy of the universe dissipates; the cosmos "cools off." Confirmation of this is found in the cosmic microwave background ( $\mathrm{CMB}$ ), which is the trace of times past when the universe was a much hotter place. According to physicists, were the universe immune to entropy, life could not exist. The so-called "arrow of time" would be non-existent, the future would be no different from the past, and evolutionary processes could not occur. Entropy, therefore, is a prerequisite for life.

When analysing the bios, it is necessary to conclude that life is opposed to the global law of entropy. Living organisms are the least entropic entities we know of - locally, until death, their entropy is negative. ${ }^{1}$ We could even venture so far as to refer to the bios as an anti-entropic process. When a biological organism is insulated from the environment, it will quickly give way to the law of entropy - its energy will dissipate, and death will follow. The bios, however, interacts with the environment, thanks to which it draws external energy to reduce its own entropy. Thus, a living organism struggles to concentrate energy and matter in itself. It fights to not "cool off" and to not "decay." This struggle can rightly be associated with natural selection. Recently, even a voice has been heard that instead of natural selection we should speak of entropic selection. ${ }^{2}$ Natural selection can be regarded as a special case of a more general law of selection arising from entropy increase. Biological life and the entropy process itself appear to be tightly interlinked. Life exists thanks to entropy, and at the same time, life suffers due to entropy. Nonetheless, it reveals that certain struggle is included in the very essence of life.

\section{Abiotic origins of life}

Underlying abiogenesis is the idea of the evolutionary shaping of life from non-living matter. The term itself imports autogeny - spontaneous generation. The original concept of autogeny took a very primitive shape, but years later returned in a far more sophisticated form - abiogenesis theory. Alexander Oparin, the Russian scholar who in 1924 published the work Происхождение жизни The Origin of Life, is recognized as the forerunner of the modern concept of abiogenesis. There he laid out the theory for the origin of life from carbon-based mol-

\footnotetext{
1 Michael E. Price, "Entropy and Selection: Life as an Adaptation for Universe Replication," Hindawi Complexity (2017): 2.

2 Irun R. CohEN, "Updating Darwin: Information and entropy drive the evolution of life," F1000Research (2016): 8.
} 
ecules, arguing for the superfluity of religious concepts of the world and creation of life by God. John Scott Haldane proffered a similar hypothesis in England. Both scientists asserted that life on Earth originated out of a long process of chemical evolution. In their subsequently published works, they introduced to protobiology the concept of the первичного бульона - primordial soup, a primitive ocean of organic compounds formed in an oxygen-free atmosphere, providing the space and the nourishment for the first living organisms. ${ }^{3}$ Here H. Urey and S. Miller's experiment proved to be ground-breaking in establishing that amino-acids could synthesize out of simple carbon-based molecules in an oxygen-free atmosphere through the application of lightning. At present, hypotheses describing the process of abiogenesis abound in number. The most recent include Sedlak and CairnsSmith's hypothesis that proposes a mineral origin of life. ${ }^{4}$

The most important thing in all modern narratives describing the origins of bios is that the first living forms originate from inanimate matter. In other words, the animate is initiated from the inanimate. Most importantly, from a theological point of view, is the following conclusion: that the cosmos from the very beginning possessed latent potency to achieve bios, and abiogenesis is the "awakening" of life.

\section{Life as an evolving gene}

The word gene is one of the most frequently used terms in science for life understood as bios. Originally, it was only a theoretical designation of a unit of heredity, allowing Darwin's theory to be married to the discoveries of Mendel. Thanks to the analysis of DNA structure, a more lucid understanding came of where and in what way that genetic information is stored. The gene is the essence of life in the opinion of many recent thinkers. R. Dawkins, in his celebrated The Selfish Gene, refers to the living organism as the gene machine and colony of genes..$^{5}$ The phenomenon of bios exists, according to Dawkins, only so that genes can propagate themselves. They are akin to master programmers, controlling life through protein synthesis. They behave similarly to a coder, who by use of a special language creates software that enables the computer to perform independently the tasks set forth. According to that idea, the

\footnotetext{
${ }^{3}$ Иванович Александр ОПАРин, Жизнь, её природа, происхождение и развитие (Москва: Наука, 1968), 44-54.

${ }^{4}$ Jerzy RąPALA, Teorie mineralnych początków życia. Studium filozoficzno-przyrodnicze (Lublin: Wydawnictwo KUL, 2016), 34-42.

5 Richard Dawkins, The Selfish Gene: 30th Anniversary Edition (Oxford: Oxford University Press, 2006), 46.
} 
nervous system is created and programmed by genes to enable the execution of tasks determined by them. ${ }^{6}$ It is worth mentioning that in 1975, E.O. Wilson in his Sociobiology formulated the problem of life in a similarly radical way. $\mathrm{He}$ added a further extrapolation asserting that genes control life even on the social level. The main paradigm in his theory was the possibility of predicting the characteristics of a species' social organization based on the knowledge of its genetic constitution. ${ }^{7}$

Despite the great hopes pinned on the concept of the gene, one must admit many doubts are stirred. M. Barbieri notes that while the phrase "genetic code" is universally accepted, there is no such consensus relating to its ontological status. ${ }^{8}$ He similarly observes that the organism is also dependent on other types of biological coding; the information about it is not restricted to DNA alone. ${ }^{9}$ Hence, there is a dearth of grounds to fully accept the perspective suggested by either Wilson or Dawkins. It must, however, be granted that the category of the gene communicates something very specific about the nature of biological life. The phenomenon of life includes itself certain information. For this reason, it has some plausibly meaning and sense. Can one brave the assertion that the phenomenon of life has a narrative structure?

\section{Theological perspective}

As the examples above have shown, the phenomenon of life is approached from a variety of perspectives. Scientific formulations reveals new horizons and enables important questions to be asked. Why is struggle inscribed into the bios? Does fully "inanimate" matter exist? Does life carry in itself information about "something more?" Theology supplies additional heuristic tools to tackle these problems. Therefore, the postulated theological perspective is not an attempt to provide quick and easy answers. It is a proposal for a change in the way of perceiving biological life. For example, the abiogenesis theory attempts to understand the animate world in the context of the inanimate - some abiotic explanation is sought for the bios. By contrast, theological insight enables matter itself to be perceived through the perspective of life, as the ultimate explanation of the world is the ever-living (semper vivus) God. Hence, biological life in its reference to God constitutes one of the hermeneutic keys to the perception

${ }^{6}$ Dawkins, The Selfish Gene, 54-55.

7 Edward Osborne WiLson, Sociobiology: The new synthesis (Cambridge-Massachusetts and others: The Belknap Press of Harvard University Press, 1975), 5.

${ }^{8}$ Marcello BARBIERI, "What is code biology?" Bio Systems nr 164(2018), 2.

9 Ibidem, 4. 
of reality. The bios in this could be termed a vestigium Dei - trace of God. ${ }^{10}$ This issue is raised outside the parameters of this article. However, it has already been described in the recent paper Theological Insight into the Phenomenon of Life: The Bios as a Vestigium Dei ${ }^{11}$.

\section{THE PHENOMENON OF LIFE: THE PSYCHE}

In Greek mythology, Psyche was a goddess depicted as a beautiful young girl with butterfly wings, a personification of the human soul. The Greek term $\psi v \chi \eta \dot{~}$ must primarily be translated as soul. However, its meaning is broader in scope and includes also the mind. The contemporary term psyche has acquired a new meaning owed to the development of modern psychology. In the common understanding, one's psyche means something different from one's soul. Still, the semantic matrix of the term can be said to revolve around a certain personal center. It is in that sense that life will be discussed here as the psyche - intelligent and conscious life. Its main aspects are intelligence, the ability to learn, cognition, memory, consciousness, identity, communication, and free will.

In a strict sense, the psyche is a field of interest of various disciplines of psychology. In its broader meaning, though, the psyche is the area of study of numerous different fields of science. The most important formulations in later analysis will be those of the philosophy of mind, neuroscience, and cognitive science.

\section{The downfall of Cartesian dualism}

Classic anthropology understands humanness to be a combination of soul and body. One of the most historically prominent concepts has been what is called Cartesian dualism. In his Meditations On First Philosophy, René Descartes used the terms "soul" and "mind" in line with the above-presented understanding of the psyche. In numerous places, however, the philosopher wrote about an extremely radical separation of the soul and the body..$^{12}$ The conscious life, according to him, is something altogether different and independent from the body and can exist without it. It is likened to an external control room from which the biological

\footnotetext{
${ }^{10}$ The vestigium Dei category derives from the theology of the image of God. Saint Bonaventure, who developed the thought, spoke about the likeness of the creation to God on three levels. The creation can be a trace (vestigium), a shadow (umbra) or an image (imago) of God.

${ }^{11}$ Kamil E. DuszeK, "Theological Insight into the Phenomenon of Life: The Bios as a Vestigium Dei," Teologia w Polsce nr 13/1(2019): 59-72.

${ }^{12}$ René Descartes, "Meditations On First Philosophy," Internet Encyclopedia of Philosophy, accessed 03.12.2019, http://selfpace.uconn.edu/class/percep/DescartesMeditations.pdf, 2-6.
} 
machinery is remotely managed. Here, one can therefore speak about a separation of the psyche from the bios, along with their dramatic incongruity. Nowadays, that approach is evidently unacceptable.

New light is cast on this problem by the discoveries of neuroscience. It is worth recalling the experiments conducted in the 1980s by the University of California academic, Benjamin Libet. Libet embarked on studies into the existence of free will, analyzing people's decision-making moment. He showed that an EEG change in the motor cortex registered $350 \mathrm{~ms}$ prior to the participants' stated decision. On the basis of these results, Libet concluded free will to be illusory. ${ }^{13}$ Those and similar studies invite numerous methodological doubts. It must be granted, however, that those studies indisputably show correlations between life on the bios and the psyche level. Nowadays, we are well aware of how bio-chemical changes in the brain can impact human conduct and thinking. For example, even a small difference in cortisol levels in the organism affects a person's mood and perception, and, consequently, decision-making. To many researchers, the discoveries of neuroscience are an argument in support of reducing life as the psyche to the categories of the bios. Theological perspective makes it possible to resist such hermeneutics. It cannot ignore, however, how the conclusion begs to be made that it is impossible to completely separate the psyche and the bios from each other. They are two correlating aspects of one phenomenon of life.

\section{The virtual machine of consciousness}

Teilhard de Chardin refers to life as an ascent of consciousness. ${ }^{14}$ Consciousness is one of the most important aspects of the psyche, currently belonging to the research areas of the philosophy of the mind. The most distinguished thinker in that field is Daniel Dennett. His theory of the mind is the stuff of many "legends" imputed to him is total reductionism, of which the end effect is a negation of consciousness. However, such radical conclusions can hardly be found in his published works. On the contrary, while pondering the ontology of the mind, Dennett writes, "Our task in not to identify Tom's thought of Spain with some physical state of his brain." 15 If anything at all, the philosopher negates neither thought nor the mind, but the so-called single stream of consciousness. That is a rejection of the ontological unity which would supply the basis for an experience of one's own

\footnotetext{
${ }^{13}$ William R. KLemm, "Free will debates: Simple experiments are not so simple", Advances in Cognitive Psychology nr 6(2010): 49-50.

${ }^{14}$ Pierre Teilhard De Chardin, The Phenomenon Of Man (London-Glasgow: Collins' ClearType Press, 1959), 166.

${ }^{15}$ Daniel Dennett, Content and consciousness (London-New York: Routledge, 2003), 18.
} 
subjectivity. According to his concept, the "I" does not constitute the ontological center of the psyche, but emerges out of many processes as the sum total of experience and a certain grammatical function. Correlating with that is Dawkins's opinion that consciousness appears when the brain's simulation of the world becomes so complete that it must contain "itself." ${ }^{16}$ Such an understanding of consciousness could be called a virtual machine.

In spite of Dennett's enormous contribution to the discipline of philosophy of the mind, his theory invites numerous reservations. In this context, the problem of transcendence reoccurs with increasing frequency. James Tartaglia, in his celebrated Philosophy in a Meaningless Life, notes that the experience of one's own consciousness demonstrates the probability that reality exceeds the world of objects. ${ }^{17}$ This recent work has re-sparked a vigorous discussion of that link between the mind and transcendence. ${ }^{18}$ Despite the academic achievements of science today, opinions held by philosophers of the mind continue to be polarized. This shows the depth and non-banality of the phenomenon of conscious life. For certain, the psyche is in part the outcome of evolutionary processes occurring on the bios level. This, however, does not change the fact that it becomes understandable only in reference to "something more."

\section{Emergence of mind}

Polish philosopher and mathematician Michal Heller notes that the evolution from a mathematical point of view corresponds to chaos theory or dynamical systems theory. ${ }^{19}$ They prove useful in describing the phenomenon called "emergence." Mathematically speaking, a non-linear and open dynamic system can represent every emergence process. This approach inspires hopes for the development of philosophical reflection. Emergence is a term denoting the process of how new forms emerge in consequence of the interaction of simpler elements. We can speak of emergence when the whole system is non-reducible to the individual parts - it does not constitute the sum total of its elements, being a new quality instead. The idea of emergence assumes, furthermore, that only in the context

\footnotetext{
${ }^{16}$ Dawkins, The Selfish Gene, 14.

${ }^{17}$ James Tartaglia, Philosophy in a Meaningless Life (London-Oxford and others: Bloomsbury Academic, 2016), 102.

${ }^{18}$ Adam Balmer, "Transcendent Reality and the Consciousness Problem," Journal of Philosophy of Life nr 7/1(2017): 1-15; Philip Goff, "Is Consciousness Transcendent? Comments on James Tartaglia's Philosophy in a Meaningless Life: A of Nihilism, Consciousness and Reality," Journal of Philosophy of Life $\mathrm{nr}$ 7/1(2017): 21-32.

${ }^{19}$ Michał Heller, Józef Życiński, Dylematy ewolucji (Kraków: Copernicus Center Press, 2016), 259-261.
} 
of a non-reducible whole is it possible to understand fully its individual elements. ${ }^{20}$ It must be noted that numerous objections are raised to the concept of emergence. It is rejected by some as philosophically incorrect, because it conceals the idea of a certain top-down causation. However, it is becoming possible and correct from a mathematical point of view, thanks to the development of Heller's theory. The significance of this lies in how extraordinarily useful the concept of emergence is in describing the relationship between the psyche and the bios.

John S. Torday's 2018 publication entitled From Cholesterol to Consciousness is worth noting. Its author outlines the hypothetical process of neuron evolution from the perspective of molecular biology. In that context, he claims consciousness can be understood as part and parcel of the natural transition from unicellular to multicellular life, possible thanks to a physiological integration of the organism with the environment. ${ }^{21}$ Natural evolution enables the progression from cholesterol to consciousness. It is therefore, a description of emergence - a qualitative leap occurs, and a new quality emerges. This idea enables the adoption of new hermeneutics when looking at life as the psyche. The psyche emerges out of the bios as a new quality non-reducible to its parts.

\section{Theological perspective}

The analyses made so far highlight emergence as a promising perspective for the perception of the phenomenon of life. The emergence of a new quality non-reducible to its parts has a deep theological foundation. After all, God, is the Love that draws the world toward Itself and that enables an entity to "become more" and achieve a new quality. Conscious and intelligent life, therefore, has its foundations both in evolution and in transcendence. ${ }^{22}$ This leads to at least two conclusions. The former is a meta-subjective proposition of a hermeneutical circle: 1. understand the psyche from the perspective of the bios, and 2. understand the bios from the perspective of the psyche. The exclusive looking at the psyche in the light of the bios does not exhaust the phenomenon of life. Also, a reciprocal perspective will be of value. The bios and psyche permeate and affect each other, although different types of causation are involved. The second conclusion is the discovery of the psyche as directed to some extent toward transcendence. Ultimately, it can

\footnotetext{
${ }^{20}$ Tomasz MAziarka, "Wiarygodność antropologii chrześcijańskiej w kontekście neurobiologii: Philipa Claytona koncepcja emergentnego umysłu," Biblioteka Teologii Fundamentalnej nr 9(2014): 225-228.

${ }^{21}$ John Steven Torday, "From Cholesterol to Consciousness," Progress in Biophysics and Molecular Biology nr 132(2018): 53.

${ }^{22}$ John F. Haught, "Theology, Evolution, and the Human Mind: How much can biology explain?” Zygon nr 44/4(2009): 929.
} 
be asserted that the psyche tells about the Divine Logos as the Omega of the world. Hence, it can be termed the umbra Dei - the shadow of God. The issue of umbra Dei has already been emphasized in the recent article Umbra Dei: A Theological Interpretation of Psychological Life. ${ }^{23}$

\section{THE PHENOMENON OF LIFE: THE ZOE}

The $z \omega \eta$ finds its source in Greek mythology. Zoe was a huntress-follower of Artemis. Of key significance is her name itself, meaning life, or rather the fullness of life. In theology the term zoe relates to the spiritual life, that continual reaching "toward" something higher. Finally, it is the possibility of realization and unification in that Fullness, "toward" which all of creation exists. Therefore, the ultimate form of existence can be called zoe. To the greatest degree of this dynamism belongs to a person through two transcendental aspects of the spirit — the reason and the will..$^{24}$

This part of the article will focus on humanness. The zoe fully realizes itself in a human being, even if the potential of transcendentality exists in all creation. Manifestations of zoe can be seen across many fields. The analyze will present the basic references to the highest transcendental function of life, according to the spiritual attitudes of faith, hope, and love.

\section{Faith and cognition}

Faith is something qualitatively distinct from cognition. Of course, we can certainly grasp the close connection between cognition and faith. At the same time, there is an important contrast: cognition belongs to the psyche, and faith belongs to the zoe. They are both parts of different planes of the phenomenon of life. Some philosophers allege faith to be a fatal error of the mind. However, from a theological point of view, faith can be understood to be an arising new quality of the phenomenon. In the Platonic era, faith was pictured as something less than full cognition, as a prelude to intellectual understanding. It seems however, that faith is neither some "pre-understanding" of scientific knowledge nor is it something worse and inferior. Instead, it reaches beyond intellectual cognition, and even surpasses it.

${ }^{23}$ Anna PĘDRAK, "Umbra Dei. A Theological Interpretation of Psychological Life," Teologia w Polsce nr 13/1(2019): 87-100.

${ }^{24}$ Gerhard Ludwig Müller, Katholische Dogmatik. Für Studium und Praxis der Theologie (Freiburg-Basel-Wien: Herder, 1995), 565. 
Joseph Ratzinger, citing Isaiah 7:9, quotes from the Septuagint, "If you do not believe, neither will you understand." This statement is not only new in its linguistic meaning, it also introduces a new outlook upon the meaning. It has something of the truth in itself, but one can never equate knowledge with faith. Every human makes essential decisions in life and can do so only on the path of faith. There are situations that allow for only a response of faith, and those responses will not commensurate with knowledge ${ }^{25}$."Faith that...", which is a certain supposition, must be distinguished from "faith in...". In the latter phrase, "faith" refers to the giving of meaning or sense, without which a human being would not find himself, his place in the world, or his purpose. That sense does not come from knowledge. A sense of meaning that human beings invent for themselves, as in the Cartesian example of cogito ergo sum, ultimately becomes absurd as illustrated by Münchhausen's attempt to pull himself out of the mire by his own hair. ${ }^{26}$ Believing in a meaning is a foundation that creation is incapable of giving to itself.

True faith is possible because of God's Revelation. Without this divine self-giving gift, faith is only a greedy wish. If God had not given Revelation, the human desire for transcendence would have been destined to fail. Nonetheless, God fully revealed Himself in Jesus Christ, so faith is not a blind fate devoid of rationality, nor it is a threadbare idea of incomprehensible philosophy. Faith is a component of zoe and leads to its fullness, to the truth of itself and of life; it leads to a special relationship with the absolute Meaning - the Logos. Faith truly allows humans to transcend the world toward a new life.

\section{Hope and purpose}

One more characteristic giving zoe its unique character are acts of hope. Hope is something different from optimism. Optimism is good and useful, especially in the difficult moments of life. It is a consequence of one's temperament and inclination, or simply put, one's predispositions. Hope is something more. The purpose of optimism is a utopia, a world without hope, concealed beneath the delusive appearance of escape from despair. Hope transcends optimism; it is directed toward happiness in a closer dimension - fulfillment of life in temporality - and a further goal - unification of the world to God through an act of Divine power and love. ${ }^{27}$ Eschatology transcends utopia.

${ }^{25}$ Joseph Ratzinger, Opera Omnia, t. IV: Wprowadzenie do chrześcijaństwa. Wyznanie Chrzest-Naśladowanie (Lublin: Wydawnictwo KUL, 2017), 71-73.

${ }^{26}$ Ibidem, 73-74.

${ }^{27}$ Ibidem, 385-386. 
According to Karl Rahner, God constructed humans as an infinite question that the human being himself cannot answer. ${ }^{28}$ God revealed Himself in the humanity of Jesus Christ so that humans could find in Him the answer. The Mystery of Christ showed that in a humanness, the bios and the psyche self-transcends to achieve a new quality - the zoe. The tension between acts of hope and optimism also exposes an emergent movement of life towards something more. The rise from terrestrial utopias to an eternal goal can be considered to be an appearance of zoe. First, it is a natural drift of life to fulfillment. On the other hand, zoe is something given as a divine-like element of life. It is the hidden potential of the phenomenon of life that unveils itself due to an encounter with a self-giving God. If God had not given this eternal goal in his promises, transcendental hope would have been only a greedy kind of wishing. One cannot speak of a hope for future life in abstraction from God's eternal promises revealed in Jesus Christ. In this context, an interesting perspective is provided by Saint John. He made use in his Gospel of all three terms describing life - bios, psyche and zoe. However, in his prologue he emphasized that, in Logos "was zoe," using that Greek word in reference to the Divine Life. Moreover, Christ comes to the world to give that zoe to us: "I am come that they may have zoe, and may have it [i.e. zoe] more abundantly" (John 10:10). If zoe is the self-transition of the cosmos into the mystery of God, it takes place thanks to that one Event - the Incarnation of Jesus Christ. ${ }^{29}$ Through Jesus Christ's self-communication to men, He made it possible for humans to strive for Transcendence. In this context, Christ becomes the hope, the promise, and the absolute future of the whole phenomenon of life.

\section{Love and relationship}

Hope is the fruit of faith; in it, life is directed toward a limitless future. That fullness of existence, to which faith provides the key, contains itself in love. Love, before which in the light of faith hope proceeds, is not something private; it is opened to the entire universe, thanks to which it can become "paradise." ${ }^{30}$ Importantly, the capacity for love is universal and proper to life as the zoe, but it manifests itself in humanity not as a whole, collectively, but primarily in the individual and the individual's relationship with God and with others.

Human life is directed toward a higher purpose, a supreme purpose. The intention of the Most High was that humans be created to love and for Love. God wanted humans in the most direct way. Every human being has a universal vocation

\footnotetext{
${ }^{28}$ Karl RAHNER, Schriftenzur Theologie I (Einsiedeln-Zürich-Köln: Benziger Verlag, 1954), 205.

${ }^{29}$ Ibidem, 188.

${ }^{30}$ Ratzinger, Opera Omnia, t. IV, 400.
} 
to be in an individual relationship with the Creator of life. Hence, humanity can find transcendental fulfillment only in communion with God. Joseph Ratzinger calls attention to the impossibility of separating human love (eros) from supernatural love (agape, caritas). Any such attempt usually ends in the deformation and adulteration of both dimensions. Restricting love to mere temporality deprives it of its deepest identity, which is infinity. Similarly, an attempt to separate the God-given agape or caritas love from nature, transforms it into a caricature. Love is the affirmation of one's existence in relation to another - "yes" in relation to "you," where "yes" is a creative act and something new. Human, to live fully, needs that "yes" from someone outside of "I." This can assist our understanding of the mystery of creation and salvation. God's love is creative; in its power it created something out of nothing and on that it founded all of reality. Even more so can salvation be perceived as the new birth of creation - the "yes" of God, the apogee completed in the Cross which causes humans to truly live. ${ }^{31}$

Love transcends biological and evolutionary processes and becomes the domain of free decision made by people. Furthermore, it is a decision and a gift, more resulting from relationship than driven by the principles of evolution. In this sense, Christ through accepting life as bios and psyche, overcomes their power in the cross and brings them to the sphere of zoe - the life that is the immortal sphere of relationship. God, who is Love, wants to give and share, and wants reciprocity of His love. That gift of love, as the highest capacity anchored in the zoe, enables a human being to transcend itself and its "I" and to respond to the one Love.

\section{Theological perspective}

The above reflections have shown that life in its most important manifestations are realized in human. Zoe is something characteristic of human beings who are capable of spiritual acts. This acts have a transcendental function due to the self-giving action of God. Especially it manifests in spiritual dynamism of love, faith, and hope. As already shown, signs of God, however, exist in all of nature. All creation tells something about God. The whole phenomenon of life is somehow a revelation of God - it reveals the traces and shadows of Divine beauty. The vestigia and the umbra Dei are at the same time vestigia Trinitatis and vestigia regni Dei - traces of the Triune God, who promises the Kingdom to Come. ${ }^{32}$

\footnotetext{
${ }^{31}$ Ibidem, 412-413.

32 Jürgen Moltmann, Bóg w stworzeniu (Kraków: Znak, 1995), 132.
} 
The theological perspective in the preceding sections allowed for a look at the bios and the psyche as the trace and shadow of God. Beside the vestigium and the umbra, we can introduce a third and most important notion — the imago Dei, i.e. image of God. Life as the zoe points most perfectly toward God, hence the imago category must refer to it. To some extent, every aspect of the phenomenon of life, including planes of the bios and the psyche, fulfills itself in the zoe understood as the image of God. The next article about the spiritual life interpreted in terms of imago Dei is already in preparation.

\section{CONCLUSION}

The phenomenon of life is one. It manifests itself on many planes, but in its essence, it is one. Such is the principal conclusion from the theological insights achieved here. Hence, in this article, the word "phenomenon" referred only to life as understood on the whole. Nowhere was there any mention of a phenomenon of the bios or of the psyche, but only the one phenomenon of life taken on its three most important planes. Another conclusion that suggests itself is the impossibility of mutual separation of these manifestations of life. Together they compose one phenomenon, and their correlations with each other must always be taken into account. What is important is also the hermeneutics arising from this: that the bios, the psyche and the zoe should be understood in their mutual context and in the light of the whole to which they belong.

The article made it possible to note that despite the multitude of ground-breaking discoveries in life's issue, the phenomenon itself surpasses their grasp. The most in-depth insight into its understanding is provided by a theological perspective, which enables life to be read in its transcendental function. Life from the very beginnings directed toward Supernaturality. The function has two polar extremities. First, life as the bios, psyche and zoe tells of God - is His trace (vestigium), shadow (umbra) and image (imago). Secondly, life is characterized by movement toward something more; it transcends itself to achieve a new quality for which the ultimate horizon is communion with God. If the theological perspective is to give us an answer to the question of the essence of the phenomenon of life, that answer can only be one, and it can only be the ever-living God. 


\section{REFERENCES}

BALMER, Adam. "Transcendent Reality and the Consciousness Problem." Journal of Philosophy of Life 7/1(2017): 1-15.

BARBIERI, Marcello. 'What is code biology?' Bio Systems 164(2018): 1-10.

CoHEN, Irun R. 'Updating Darwin: Information and entropy drive the evolution of life.' F1000Research (2016): 1-12.

Dawkins, Richard. The Selfish Gene: 30th Anniversary Edition. Oxford: Oxford University Press, 2006.

Dennett, Daniel. Content and consciousness. London-New York: Routledge, 2003.

Descartes, René. "Meditations On First Philosophy." Internet Encyclopedia of Philosophy, accessed 01.12.2019, http://selfpace.uconn.edu/class/percep/DescartesMeditations.pdf.

Duszek, Kamil E. "Theological Insight into the Phenomenon of Life: The Bios as a Vestigium Dei." Teologia w Polsce 13/1(2019): 59-72.

GofF, Philip. "Is Consciousness Transcendent? Comments on James Tartaglia's Philosophy in a Meaningless Life: A of Nihilism, Consciousness and Reality." Journal of Philosophy of Life 7/1(2017): 21-32.

HaUGHT, John F. "Theology, evolution, and the human mind: how much can biology explain?" Zygon 44/4(2009): 921-931.

Heller, Michał, Życiński, Józef. Dylematy ewolucji. Kraków: Copernicus Center Press, 2016.

Klemm, William R. "Free will debates: Simple experiments are not so simple." Advances in Cognitive Psychology 6(2010): 47-65.

MaZiarka, Tomasz. "Wiarygodność antropologii chrześcijańskiej w kontekście neurobiologii: Philipa Claytona koncepcja emergentnego umysłu." Biblioteka Teologii Fundamentalnej 9(2014): 217-243.

Moltmann, Jürgen. Bóg w stworzeniu, Kraków: Znak, 1995.

MüLlER, Gerhard Ludwig. Katholische Dogmatik. Für Studium und Praxis der Theologie, Freiburg-Basel-Wien: Herder, 1995.

ОПАРин, Иванович Александр. Жизнь, её природа, происхождение и развитие. Москва: Наука, 1968.

PęDRAK, Anna. "Umbra Dei. A theological Interpretation of Psychological Life." Teologia w Polsce 13/1(2019): 87-100.

PrICE, Michael E. "Entropy and Selection: Life as an Adaptation for Universe Replication." Hindawi Complexity (2017): 1-5.

RAHNER, Karl. Schriftenzur Theologie I. Einsiedeln-Zürich-Köln: Benziger Verlag, 1954. 
Rąpata, Jerzy. Teorie mineralnych początków życia. Studium filozoficzno-przyrodnicze. Lublin: Wydawnictwo KUL, 2016.

Ratzinger, Joseph. Opera Omnia, t. IV: Wprowadzenie do chrześcijaństwa. Wyznanie - Chrzest-Naśladowanie. Lublin: Wydawnictwo KUL, 2017.

Tartaglia, James. Philosophy in a Meaningless Life. London-Oxford and others: Bloomsbury Academic, 2016.

Teilhard de Chardin, Pierre. The Phenomenon Of Man. London-Glasgow: Collins' Clear-Type Press, 1959.

TordaY, John Steven. "From cholesterol to consciousness." Progress in Biophysics and Molecular Biology 132(2018): 52-56.

WiLson, Edward Osborne. Sociobiology: The new synthesis. Cambridge-Massachusetts and others: The Belknap Press of Harvard University Press, 1975.

\author{
FENOMEN ŻYCIA W PERSPEKTYWIE \\ TEOLOGICZNEJ:WPROWADZENIE W BIOS, PSYCHE I ZOE
}

S T R E S Z C Z E N I E

Życie jest pięknym i wyjątkowym zjawiskiem. Nie można go opisać za pomocą jednej definicji, ponieważ przejawia się na wiele różnych sposobów. Dlatego fenomen życia musi zostać uchwycony jako całość z uwzględnieniem jego podstawowych płaszczyzn. Autorzy pracy przeprowadzili interdyscyplinarne badania naukowe. Ich zadaniem było zgłębienie kwestii życia na trzech płaszczyznach: bios (życie w jego podstawowych przejawach), psyche (życie inteligentne i świadome) i zoe (życie, które przekracza siebie). Zebrane przez nich dane nabierają szczególnego znaczenia dzięki perspektywie teologicznej. Jest to podejście określające metodę pracy - ma ona interdyscyplinarną charakterystykę oraz jest wyrazem myślenia teologicznego. Umożliwia to zrozumienie całego fenomenu w jego transcendentalnej funkcji. Życie od samego początku wyłania się ku „czemuś więcej”. Ostatecznym celem tego transcendentalnego dynamizmu jest wiecznie żywy Bóg.

Słowa kluczowe: bios; psyche; zoe; religia i nauka; transcendentalność; współczesna teologia. 